\title{
Pengaruh Model Spasial Based Learning terhadap Kemampuan Berpikir Kritis Siswa
}

\author{
Agustinus Hale Manek ${ }^{1}$, Dwiyono Hari Utomo ${ }^{1}$, Budi Handoyo ${ }^{1}$ \\ ${ }^{1}$ Pendidikan Geografi-Universitas Negeri Malang
}

\begin{tabular}{l}
\hline \hline INFO ARTIKEL \\
\hline Riwayat Artikel: \\
Diterima: 06-02-2019 \\
Disetujui: 16-04-2019 \\
\hline
\end{tabular}

\section{Kata kunci:}

spasial based learning;

learning style;

critical thinking skills;

gaya belajar;

kemampuan berpikir kritis

\begin{abstract}
ABSTRAK
Abstract: Spasial Based Learning Model has provided an alternative to Geography learning. SBL model can teach and improve critical thinking skill. This research was aimed to increase the ability to think critically through SBL model. The study design used a quasi-experiment with the design of pretest-posttest, nonequivalent control group design. The participants are students of Senior High School XI S.1 and XI S.2 of SMA Negri 1 Atambua. The results of the independent sample t-test supported by SPSS 16.00 for windows show that the value of Sig. (2-tailed) of 0,000 smaller than 0.05. Based on the results of the analysis it was concluded that there was a significant effect of the SBL model on students' critical thinking abilities. It means that an increase in critical thinking skill is a consequence of learning through the SBL model.
\end{abstract}

\begin{abstract}
Abstrak: Model Spasial Based Learning telah memberikan alternatif pada pembelajaran geografi. Model SBL dapat membelajarkan dan meningkatkan kemampuan berpikir secara kritis. Penelitian ini bertujuan untuk mengetahui pengaruh model SBL terhadap kemampuan berpikir kritis siswa. Rancangan penelitian ini menggunakan quasi experiment dengan desain pretest-posttest nonequivalent control group desing. Subjek penelitian adalah siswa kelas XI S.1 dan XI S.2 SMA Negeri 1 Atambua. Hasil uji independent sample t-test dengan bantua SPSS 16.00 for windows menunjukan bahwa nilai Sig. (2-tailed) sebesar 0,000 yang lebih kecil dari 0,05. Berdasarkan hasil analisis disimpulkan bahwa terdapat pengaruh signifikan model SBL terhadap kemampuan berpikir kritis siswa. Hal ini berarti peningkatan kemampuan berpikir kritis merupakan konsekuensi pembelajaran melalui model SBL.
\end{abstract}

\author{
Alamat Korespondensi: \\ Agustinus Hale Manek \\ Pendidikan Geografi \\ Universitas Negeri Malang \\ Jalan Semarang 5 Malang \\ E-mail: agustinushalemanek@gmail.com
}

Perkembangan pembelajaran saat ini diharapkan peserta didik dihadapkan langsung pada permasalahan dan pemecahannya secara nyata. Tujuan dari pembelajaran ini agar peserta didik mandiri dalam belajar, serta mampu meningkatkan kepercayaan diri pada pemecahan masalah yang dihadapi pada proses pembelajaran. Hal ini, sesuai dengan kecakapan thingking and learning. Kecakapan yang dimaksud adalah memecahkan masalah (Cromley, 2000); (Mason, 2007). Kemampuan memecahkan masalah merupakan kecakapan hidup yang harus dimiliki peserta didik abad 21 untuk menjadi manusia yang berkualitas. Berdasarkan " $21^{\text {st }}$ Century Partnership Learning Framework", keahlian dan kompetensi sumber daya manusia abad 21 yang harus dimiliki, salah satunya adalah kemampuan berpikir secara kritis kaitannya pada pemecahan masalah (BSNP, 2010). Kemampuan berpikir secara kritis adalah kemampuan yang mengarahkan peserta didik untuk merumuskan masalah, mengidentifikasi masalah, memecahkan masalah dan memberikan argumen secara logis tentang suatu permasalahan (Wijayanti, Sumarmi, Amirudin, 2016). Senada dengan itu, (Trilling, 2009) menyatakan bahwa kemampuan berpikir kritis dalam pemecahan suatu permasalahan merupakan kemampuan yang harus dimiliki setiap peserta didik pada abad 21.

Berpikir kritis erat kaitannya dengan cara berpikir dalam pengambilan keputusan yang dilakukan secara sadar, sistemik dan logis. Menurut (Styron, 2014); (Bialik, 2017) mengungkapkan bahwa kemampuan berpikir kritis merupakan proses yang dilakukan secara aktif, terampil dalam konsep, menerapkan, menganalisis, mengevaluasi, dan mensintesis informasi yang dikumpulkan dari hasil observasi, pengelaman, penalaran, refleksi, dan komunikasi sebagai dasar dalam bertindak serta mengambil keputusan. Sejalan dengan itu (Ennis, 1993) mengungkapkan, berpikir kritis merupakan proses berpikir pada peserta didik dalam mengambil keputusan rasional berdasarkan apa yang diyakininya. Sesuai dengan indikator kemampuan berpikir kritis, yaitu (1) kemampuan dalam merumuskan masalah, (2) memberi argumen, (3) melakukan deduksi dan induksi, (4) melakukan evaluasi, dan (5) memutuskan dan melaksanakan (Ennis, 1991). 
Pada pembelajaran geografi, kemampuan berpikir kritis peserta didik dapat dibelajarkan dan ditingkatkan. Menurut (Utomo, 2016) mengungkapkan bahwa meningkatkan kemampuan berpikir kritis dapat terjadi karena konsekuensi pembelajaran pada kegiatan pembelajaran. Lebih lanjut, Utomo menegaskan apabila siswa belajar tanpa tekanan, mendiskusikan pelajaran secara berkelompok dengan pembelajaran yang tepat atau sinkron, dan terjadi peningkatan hasil belajar setelah proses pembelajaran menunjukkan kemampuan berpikir kritis dapat diajarkan dan ditingkatkan. Berpikir kritis merupakan atribut penting dalam perkembangan intelektual, akuisisi pengetahuan, dan pemanfaatan pengetahuan peserta didik sehingga mengharuskan pendidik dapat melatih dan mengasah kemampuan tersebut (Gul, 2014). Hal ini dikarenakan, kemampuan berpikir kritis bukanlah respon otomatis, melainkan keterampilan yang harus diajarkan, dipupuk, dan didorong pada proses pembelajaran (Sharma, 2000). Pentingnya kemampuan berpikir secara kritis bagi peserta didik dalam kehidupan sehari-hari diantaranya untuk menyelesaikan permasalahan, menerapkan konsep dan menghubungkan konsep yang dipelajari (Saurino, 2008); (Wolf, 2010). Berdasarkan hal tersebut, kemampuan berpikir kritis merupakan kemampuan yang diperlukan setiap peserta didik dalam menghadapi perubahan dan tantangan-tantangan pada proses pembelajaran.

Membelajarakan dan meningkatkan kemampuan berpikir kritis membutuhkan strategi dan model pembelajaran yang tepat dan sinkron. Model pembelajaran yang tepat digunakan untuk mamfasilitasi peningkatan kemampuan berpikir kritis adalah model Spasial Based Learning (SBL). Model SBL memiliki keunggulan salah satunya adalah dapat meningkatkan kemampuan berpikir kritis (Handoyo, 2017a). Penerapan model SBL diperlukan beberapa urutan tahapan kegiatan, meliputi (1) orientasi spasial dan pemetaan, (2) identifikasi dan perumusan masalah, (3) pengumpulan data, (4) pengorganisasian data, (5) analisis data secara spasial, (6) kesimpulan, (7) komunikasi dan (8) refleksi (Handoyo, 2017a). Tujuan utama dari model pembelajaran SBL adalah membawa peserta didik mengamati, mengidentifikasi dan mempelajari permasalahan di lingkungan sekitar secara nyata. Pada proses pembelajaran melalui model SBL peserta didik dibimbing oleh pendidik untuk belajar di luar kelas terkait dengan fenomena yang terjadi di lingkungan sekitar. Pembelajaran berbasis spasial pada pembelajaran geografi membutuhkan siswa yang mampu berhipotesis, menganalisis dan mengevaluasi data spasial untuk menjawab beragam pertanyaan yang muncul atau ditemukan (Gersmehl, 2008). Tahapan pembelajaran melalui model SBL dapat melatih dan membelajarkan peserta didik dalam berpikir secara kritis. Hal ini sesuai pendapat (Utomo, 2016) bahwa membelajarkan kemampuan berpikir kritis membutuhkan kemampuan untuk mengidentifikasi masalah, mencari solusi, memahami prioritas penyelesaian masalah, menggunakan bahasa yang tepat, jelas, dan tegas, menginterpretasi data, menarik kesimpulan, dan mengeneralisasi data.

Pembelajaran menggunakan model SBL memberikan alternatif dalam pembelajaran geografi. Model pembelajaran ini mengarahkan peserta didik belajar memahami fenomena geosfer dipermukaan bumi secara spasial, sehingga pembelajaran geografi menjadi lebih konkret dan kontekstual (Handoyo, 2017a). Untuk mengkaji secara mendalam fenomena alam maupun budaya maka peserta didik harus mengetahui di mana lokasi keberadaan, mengapa terjadi di tempat atau lokasi tersebut, dan bagaimana perkembangannya. Untuk membelajarkan fenomena alam maupun budaya pada pembelajaran geografi, alternatif yang dapat diambil adalah penggunaan model pembelajaran SBL karena model ini menjadikan ruang sebagai basis pembelajaran untuk menanamkan pengetahuan geografi secara mendalam. Selain itu, model SBL membantu dalam meningkatkan kapasitas peserta didik untuk membangun pengetahuan dan keterampilan geografi secara lebih mandiri dalam memfasilitasi peserta didik untuk mengenali masalah, mengumpulkan data, mengorganisasi data, menganalisis data, dan membuat kesimpulan secara spasial.

\section{METODE}

Penelitian kuantitatif ini menggunakan rancangan eksperimen semu (quasi experiment) dengan desain pretest-posttest nonequivalent control group desain Penggunaan rancangan eksperimen semu karena pada penelitian ini tidak dapat mengendalikan sepenuhnya kedua kelompok yang diteliti dari pengaruh variabel luar lainnya. Desain penelitian disajikan pada tabel 1.

Tabel 1. Desain Pretest-Posttest Nonequivalent Control Group Design

\begin{tabular}{cccc}
\hline Kelompok & Pretest & Perlakuan & Posttest \\
\hline Eksperimen & $\mathrm{O}_{1}$ & $\mathrm{X}$ & $\mathrm{O}_{2}$ \\
Kontrol & $\mathrm{O}_{3}$ & - & $\mathrm{O}_{4}$ \\
\hline
\end{tabular}

Sumber: (Sugiyono, 2017)

Keterangan:

$\mathrm{O}_{1}$ : Berpikir kritis awal (Pretest) kelas eksperimen

$\mathrm{O}_{2}$ : Berpikir kritis akhir (Posttest) kelas eksperimen

$\mathrm{X}$ : Pembelajaran model Spasial Based Learning

$\mathrm{O}_{3}$ : Berpikir kritis awal (pretest) kelas kontrol

$\mathrm{O}_{4}$ : Berpikir kritis akhir (posttest) kelas kontrol 
Subjek pada penelitian ini adalah kelas XI Sosial SMA Negeri 1 Atambua. Kelas XI Sosial 1 sebagai kelas eksperimen dan kelas XI Sosial II sebagai kelas kontrol. Kelas eksperimen pada pembelajarannya menggunakan model SBL, sedangkan kelas kontrol menggunakan pembelajaran konvensional atau yang biasa digunakan. Data kemampuan berpikir kritis diperoleh dari tes uraian, dan dinyatakan dalam bentuk skor. Data kemampuan berpikir kritis yang dianalisis adalah data gain score. Gain score diperoleh dari selisi nilai pretest dan posttest yang bertujuan untuk mengetahui peningkatan kemampuan berpikir kritis pada kelas eksperimen dan kelas kontrol. Analisis data untuk mengatahui perbedaan peningkatan kemampuan berpikir kritis kedua kelas menggunakan uji independent sample t-test dengan bantua SPSS 16.00 for windows. Nilai kemampuan berpikir kritis yang diperoleh pada kelas eksperimen dan kontrol dikelompokkan berdasarkan pengkategorian skor kemampuan berpikir kritis. Pengelompokan kemampuan berpikir kritis dapat dilihat pada tabel 2.

Tabel 2. Pengategorian Skor Kemampuan Berpikir Kritis

\begin{tabular}{cc}
\hline Nilai & Klasifikasi \\
\hline $81-100$ & Kritis sekali \\
$66-80$ & Kritis \\
$56-65$ & Cukup kritis \\
$41-55$ & Kurang kritis \\
$0-40$ & Tidak kritis \\
\hline
\end{tabular}

Sumber: (Arikunto, 2001)

\section{HASIL}

\section{Data Kemampuan Berpikir Kritis}

Hasil penelitian yang diperoleh berupa data kemampuan berpikir kritis awal (pretest) dan akhir (posttest) kelas eksperimen dan kontrol. Hasil pretes dan posttest kemampuan berpikir kritis yang diperoleh selanjutnya dihitung nilai gain score. Data nilai gain score diperoleh dari selisi antara nilai pretest dan posttest. Berdasarkan nilai gain score dapat dilihat apakah terjadi peningkatan atau sebaliknya dari tes kemampuan berpikir kritis setelah diberi perlakuan atau pembelajaran. Data nilai pretest, posttest dan gain score dapat dilihat pada tabel 3 .

Tabel 3. Deskripsi Nilai Gain Score

\begin{tabular}{lccc}
\hline \multicolumn{1}{c}{ Kelas } & Nilai Rata-rata Pretest & Nilai Rata-rata Posttest & Nilai Rata-rata Gain Score \\
\hline Kelas Eksperimen & 50,72 & 75,92 & 25,20 \\
Kelas Kontrol & 50,53 & 64,04 & 13,51 \\
\hline
\end{tabular}

\section{Sumber: Hasil Analisis Peneliti, 2019}

Tabel 3 menunjukkan rata-rata nilai pretest, posttest dan gain score kedua kelas, baik kelas eksperimen yang diberi perlakuan atau pembalajaran dengan mengunakan model pembelajaran SBL maupun kelas kontrol dengan pembelajaran konvensional atau yang biasa digunakan. Nilai rata-rata siswa pada kelas eksperimen dengan mengunakan model pembelajaran SB) sebesar 25,20 lebih tinggi dari kelas kontrol sebesar 13,51. Selisih rata-rata gain score kedua kelas sebesar 11,69. Perbandingan nilai rata-rata kemampuan berpikir kritis awal (pretest), akhir (posttest) dan gain score disajikan pada gambar 1.

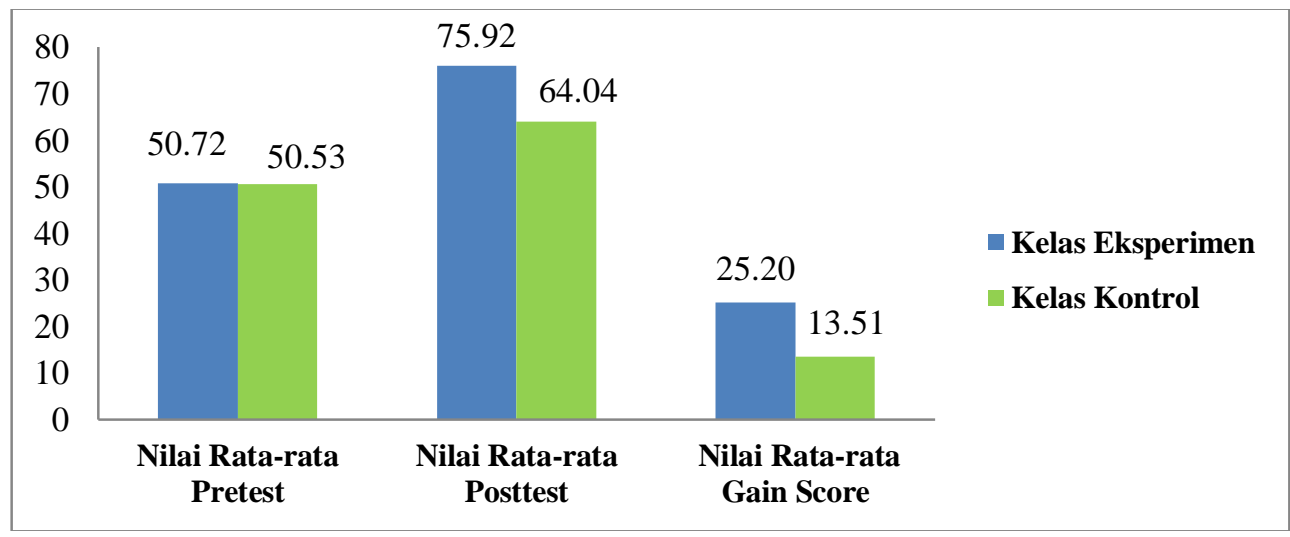

Gambar 1. Rata-rata Nilai Pretest, Posttest, dan Gain Score Data Gaya Belajar 


\section{Uji Hipotesis}

Data gain score kemampuan berpikir kritis siswa yang diperoleh kemudian dianalisis menggunakan uji independent sample t-test dengan bantua SPSS 16.00 for windows. Sebelum dilakukan uji hipotesis, terlebih dahulu dilakukan uji prasyarat analisis yang meliputi uji homogenitas dan normalitas data. Berdasarkan hasil uji homogenitas dan normalitas diperoleh bahwa data berdistribusi normal dan mempunyai varians yang homogen. Ringkasan hasil uji independent sample t-test disajikan pada tabel 4.

Tabel 4. Ringkasan Hasil Uji Independent Sample t-test

\begin{tabular}{lccccc}
\hline \multicolumn{4}{c}{ Independent Samples Test } \\
& \multicolumn{3}{c}{ Levene's Test for Equality of Variances } & \multicolumn{1}{c}{ t-test for Equality of Means } \\
\cline { 2 - 6 } & $\mathrm{F}$ & Sig. & $\mathrm{t}$ & df & Sig. (2-tailed) \\
\hline Kemampuan Berpikir Kritis & .797 & .375 & 5.273 & 61 & .000 \\
\hline
\end{tabular}

Sumber: Hasil Analisis Peneliti (2019)

Berdasarkan hasil uji hipotesis diperoleh $\mathrm{t}=5,273$ dengan $\mathrm{df}=61$ dan nilai Sig. $=0$. Memperhatikan rata-rata gain score kemampuan berpikir kritis siswa dengan model pembelajaran SBL sebesar 25,53 000 yang lebih kecil dari 0,05. Hasil perhitungan ini dapat disimpulkan bahwa kemampuan berpikir kritis antara pembelajaran dengan menggunakan model SBL dan pembelajaran konvensional atau yang biasa digunakan terdapat perbedaan yang signifikan lebih tinggi daripada rata-rata kemampuan berpikir kritis siswa menggunakan pembelajaran konvensional atau yang biasa digunakan sebesar 13,23. Berdasarkan hasil analisis data, $\mathrm{H}_{0}$ ditolak dan $\mathrm{H}_{1}$ diterima sebagai hasil penelitian, maka disimpulkan bahwa model pembelajaran SBL berpengaruh signifikan terhadap kemampuan berpikir kritis siswa.

\section{PEMBAHASAN}

\section{Pengaruh Model Pembelajaran Spasial Based Learning terhadap Kemampuan Berpikir Kritis}

Temuan pada penelitian ini menunjukkan bahwa pembelajaran menggunakan model SBL berpengaruh positif terhadap peningkatan kemampuan berpikir kritis siswa. Artinya, kemampuan berpikir kritis siswa dengan menggunakan model pembelajaran SBL lebih meningkat dibandingkan dengan pembelajaran konvensional atau yang biasa digunakan. Model pembelajaran SBL menjadikan ruang sebagai basis pembelajaran, orientasi dari pembelajaran menggunakan model ini adalah kegiatan yang dilakukan peserta didik secara aktif. Ruang yang menjadi basis pembelajaran terdapat berbagai fenomena atau permasalahan geografi yang terjadi sehingga dari permasalahan yang terjadi peserta didik dilatih untuk berhipotesis, menganalisis dan mengevaluasi serta menjawab berbagai permasalahan yang terjadi secara kontekstual pada proses pembelajaran. Hal ini menunjukkan, indikator kemampuan berpikir kritis menurut (Ennis, 1991) yang digunakan pada penelitian ini, dibelajarkan dan dilatih pada proses pembelajaran menggunakan model SBL. Argumen logis ini sesuai dengan teori bahwa model SBL memiliki keunggulan yaitu salah satunya meningkatkan kemampuan berpikir kritis.

Pembelajaran melalui model SBL memberikan pengaruh positif pada peningkatan kemampuan berpikir kritis siswa. Peningkatan kemampuan berpikir kritis siswa merupakan konsekuensi positif dari pelaksanaan setiap tahapan/sintaks pembelajaran menggunakan model SBL mulai dari tahapan (1) orientasi spasial, (2) identifikasi dan perumusan masalah, (3) pengumpulan data, (4) pengorganisasian data, (5) analisis data secara spasial, (6) kesimpulan, (7) komunikasi, dan (8) refleksi. Rangkaian tahapan pembelajaran ini memberikan pengaruh positif bagi peningkatan kemampuan berpikir kritis siswa, sesuai dengan indikator, (1) merumuskan masalah, (2) memberi argumen, (3) melakukan deduksi, (4) melakukan induksi, (5) melakukan evaluasi, serta yang terakhir (6) memutuskan dan melaksanakan. Hal ini sesuai dengan pendapatnya (Utomo, 2016) yang mengungkapkan bahwa meningkatnya kemampuan berpikir kritis dapat tejadi karena konsekuensi pembelajaran pada kegiatan pembelajaran yang dilakukan tanpa tekanan, mendiskusikan pembelajaran secara berkelompok dengan pembelajaran yang tepat dan sinkron.

Peningkatan kemampuan berpikir kritis dikarenakan pada setiap tahapan/sintaks pembelajaran SBL yang dijalankan melatih dan membelajarkan peserta didik pada peningkatan kemampuan berpikir kritis. Tahapan pembelajaran yang memberikan pengaruh positif terhadap peningkatan kemampuan berpikir kritis, meliputi orientasi spasial dan pemetaan. Pada tahapan ini peserta didik dalam kelompok secara langsung mengenali fenomena geosfer yang berkaitan dengan permasalahan lingkungan akibat pertambangan bahan galian C (yang dibagi menjadi dua titik pengamatan), dan peserta didik dapat mengetahui secara langsung karakteristik, lokasi dan argumentasi mengapa mereka ada. Peserta didik dalam kelompok menggunakan bantuan GPS Essential untuk mengetahui secara detail lokasi tempat terjadinya fenomena geografi atau permasalahan geografi pada lokasi pengamatan. Kegiatan selanjutnya, peserta didik dalam kelompok menentukan satu permasalahan yang terjadi akibat pertambangan (bahan galian C) yang akan menjadi topik diskusi dalam kelompok. Pada tahapan ini peserta didik dilatih dan dibelajarkan untuk bagaimana menemukan permasalahan geografi yang ditimbulkan akibat pertambangan (bahan galian C) secara nyata di lapangan. Tahapan ini juga melatih dan membelajarkan peserta didik dalam penggunaan aplikasi GPS Essential sehingga mampu memahami dan mengatahui cara penggunaannya. 
Kedua, identifikasi dan perumusan masalah. Berbagai permasalahan geografi dan fenomena akibat pertambangan (bahan galian C) yang ditemukan oleh peserta didik di lapangan kemudian dilakukan identifikasi. Tahapan identifikasi ini merupakan tahapan mencari dan mengetahui secara mendalam permasalahan yang terjadi dan dampaknya terhadap lingkungan dan manusia. Untuk mengidentifikasi masalah peserta didik harus memiliki pengetahuan konseptual dan faktual dari fenomena yang akan dipelajari (Handoyo, 2017b). Hal ini agar dari tahapan mengidentifikasi, peserta didik diharapkan mampu permasalahan secara nyata. Permasalahan yang dianggap urgen dalam kelompok dipilih sebagai permasalahan yang menjadi topik diskusi pada setiap kelompok.

Topik diskusi yang telah dipersiapkan akan membangun pengetahuan peserta didik sehingga membantu menjadi seorang pemikir kritis (Boyles, 2014). Berdasarkan topik permasalahan yang dipilih setiap kelompok, langkah selanjutnya yaitu secara kelompok menentukan rumusan masalah untuk menjawab permasalahan yang dipilih. Pada tahapan ini setiap kelompok berdiskusi menentukan pertanyaan-pertanyaan yang mampu menjawab permasalahan yang menjadi topik pembahasan dalam kelompok. Tahapan yang kedua pada pembelajaran menggunakan model SBL menunjukkan bahwa peserta didik dilatih untuk merumuskan masalah sesuai permasalah yang ditemukan dalam kelompok.

Ketiga, pengumpulan data. Pada tahapan pengumpulan data peserta didik dilatih memberikan argument berdasarkan temukan data lapangan. Argumen logis yang diberikan terkait dengan permasalahan dan rumusan masalah yang dibuat dalam kelompok. Argumen logis akan menjadi dasar pengumpulan data dalam kelompok. Pada proses pembelajaran peserta didik secara berkelompok melakukan pengumpulan data secara langsung di lapangan. Peserta didik dalam kelompok memiliki argumentasi yang berbeda dalam menemukan data di lapangan, argumen dari masing-masing peserta didik yang berbeda di satukan sesuai kesepakan atau diskusi bersama untuk menjawap perumusan masalah yang telah dibuat dalam kelompok. Menurut (Slavin, 2008) menjelaskan bahwa kegiatan kelompok merupakan satu metode untuk mendorong keterlibatan peserta didik secara maksimal. Selain itu, peserta didik lebih aktif dalam berpikir, memberikan argumen dan berdiskusi dalam kelompok tanpa beban dan rasa malu dalam menyampaikan pendapat. Hal ini terlihat ketika interaksi antara peserta didik dalam kelompok pada saat pembelajaran berlangsung. Pada tahapan pembelajaran ini, indikator kemampuan berpikir kritis yang kedua, yaitu memberikan argumen terakomodir pada kegiatan ini.

Keempat, pengorganisasian data. Pada tahapan pengorganisasian data peserta didik dalam kelompok mengatur data yang diperoleh pada tahapan sebelumnya. Perolehan data lapangan ditampilkan dalam bentuk tabel dan narasi sesuai kebutuhan. Peserta didik pada setiap kelompok memberikan penjelasan sesuai tabel yang dibuat dan memberikan narasi sebagai penjelasan atas temuan data lapangan dengan dilengkapi kajian kepustakaan dari berbagai referensi dan internet. Tahapan ini juga melatih peserta didik memberikan argumentasi dan pemikiran logis terkait data yang telah dikumpulkan dan mengeneralisasikan data, dan membuat table untuk memberikan penjelasan logis terkait temuan data di lapangan. Hal ini mengambarkah bahwa, tahapan mengorganisasi data mengakomodir kemampuan peserta didik dalam berpikir kritis terutama pada indikator melakukan induksi. Kegiatan melakukan induksi dilakukan dengan melakukan pengumpulan data, membuat generalisasi data (berupa tabel, diagram, dan garafik), membuat simpulan terkait hipotesis, serta memberi asumsi yang logis (Ennis, 1985).

Kelima, analisis data secara spasial. Tahapan ini mengharuskan peserta didik dalam kelompok untuk melakukan analisis data temuan secara spasial. Analisis secara spasial dilakukan berdasarkan tema analisis yang telah ditentukan. Tema analisis yang digunakan yaitu analisis pola dan struktur. Pada tahapan analisis spasial menggunakan tema analisis pola, penekanan utamanya adalah peserta didik menjelaskan sebaran elemen-elemen pembentuk ruang yang berada pada lokasi pengamatan. Selanjutnya, peserta didik dalam kelompok menjawab pertanyaan yang telah dibuat yang merujuk pada pertanyaan $5 \mathrm{~W}$ dan $1 \mathrm{H}$. Selain itu, peserta didik dalam kelompok menekankan analisis pada elemen-elemen pembentuk ruang yang telah ditemukan khususnya yang berkaitan dengan permasalahan yang menjadi topik diskusi dalam kelompok. Tujuannya agar dapat menjawab pertanyaan yang telah disusun dan adanya kemendalaman analisis terkait permasalahan yang di angkat. Kedalaman analisis akan terlihat dari jawaban yang dimunculkan masing-masing kelompok. Kegiatan pembelajaran pada tahapan ini mengakomodir kemampuan peserta didik dalam melakukan deduksi. Kemampuan melakukan deduksi terlihat dari jawaban dan pernyataan peserta didik atas pertanyaan yang dibuat pada masing-masing kelompok.

Keenam, menarik kesimpulan. Pada tahapan ini peserta didik menarik kesimpulan berdasarkan hasil analisis yang dilakukan pada tahapan sebelumnya. Pada proses menarik kesimpulan melatih peserta didik mencari hubungan terhadap data yang dianalisis. Penarikan kesimpulan dilakukan oleh masing-masing kelompok. Kesimpulan hasil analisis kelompok akan menjadi bahan evaluasi dan pengambilan keputusan berkaitan dengan solusi atas permasalahan yang menjadi topik dalam kelompok. Selain itu, penarikan kesimpulan berdasarkan hasil analisis pada masing-masing kelompok sebagai upaya untuk menentukan kemungkinan-kemungkinan yang dapat dilakukan dalam memberikan solusi dan penanggulangannya. Penarikan kesimpulan akan dijadikan prinsip umum dengan memperhatikan hasil verifikasi dari permasalahan yang menjadi pembahasan (Syah, 2004). Kegiatan penarikan kesimpulan berdasarkan hasil analisis tiap kelompok dapat mengembangkan kemampuan berpikir kritis peserta didik sesuai dengan indikator kemampuan memutuskan dan melaksanakan.

Ketujuh, komunikasi. Semua informasi yang telah dikumpulkan setiap kelompok pada tahapan sebelumnya dibuat dalam bentuk makalah sebagai laporan akhir kelompok. Laporan masing-masing kelompok yang telah dipersiapkan dengan baik, kemudian dipresentasikan kepada kelompok lain. Pada tahapan ini peserta didik berdiskusi, menanggapi, memberikan pertanyaan, solusi dan alternatif yang dapat diambil terkait dengan hasil presentasi dari masing-masing kelompok. Persiapan laporan akhir mendorong partisipasi aktif peserta didik untuk membuat konsep dan persiapan memaparkan hasil akhir kelompok. 
Kegiatan mengomunikasikan hasil diskusi kelompok memberikan gambaran bahwa kemampuan berpikir kritis pada indikator kemampuan melakukan evaluasi dilatih dan dibelajarkan dari rangkaian kegiatan presentasi kelompok. Senada dengan pendapat Huang dalam (Utomo, 2016) bahwa membelajarkan kemampuan berpikir kritis harus melibatkan peserta didik dalam kegiatan diskusi dan penalaran, mencari bukti untuk kesimpulan, membuat keputusan, dan menemukan solusinya.

Kedelapan, refleksi. Refleksi merupakan tahapan yang terakhir dari pembelajaran menggunakan model SBL. Pada tahapan ini peserta didik melakukan refleksi atas pembelajaran yang telah dilakukan, mulai dari tahapan yang pertama hingga tahapan yang terakhir. Peserta didik dalam kelompok memberikan penilaian atas pembelajaran yang telah mereka lakukan. Sesuai dengan pengelaman dalam belajar menggunakan model ini peserta didik menyampaikan sejauh mana tujuan pembelajaran yang dicapai dan menyampaikan usulan perbaikan yang perlu dilakukan ke depan. Hal ini dikarenakan pengalaman belajar akan memberikan pengetahuan kepada peserta didik melalui sejumlah penemuan yang dihasilkan pada pembelajaran (Sularmi, Utomo, Ruja, 2018).

Rangkaian kegiatan yang dijalankan pada proses pembelajaran menggunakan model SBL menempatkan pendidik sebagai fasilitator dalam membimbing peserta didik menjalankan setiap tahapan pada pembelajaran. Hal ini bertujuan untuk dapat meningkatkan aktivitas dan kreativitas peserta didik secara mandiri dalam berpikir untuk menemukan dan memecahkan permasalahan di lingkungan sekitar secara nyata. Proses pembelajaran yang dijalankan memberikan kemudahan kepada peserta didik agar dapat belajar dalam suasana yang menyenangkan, dan berani mengemukakan pendapat secara terbuka. Rasa gembira, penuh semangat, tidak cemas, dan berani mengemukakan pendapat secara terbuka merupakan modal dasar bagi peserta didik untuk tumbuh dan berkembang menjadi manusia yang siap beradaptasi, menghadapi berbagai kemungkinan, dan memasuki era globalisasi yang penuh dengan berbagai tantangan (Mulyasa, 2013). Penerapan model pembelajaran SBL menjadikan pendidik bukan lagi satu-satunya sumber informasi bagi peserta didik dalam menyelesaikan dan menjawab permasalahan yang ditemukan pada proses pembelajaran.

Salah satu keunggulan model SBL yang ditemukan pada penelitian ini yaitu seluruh aktivitas yang dilakukan peserta didik diarahkan untuk mencari dan menemukan pengetahuan secara mandiri. kegiatan pembelajaran melalui model SBL ini dapat menumbuhkan sikap percaya diri dan motivasi dalam belajar. Hal ini menunjukkan, pembelajaran menggunakan model SBL dapat menumbuhkan pengetahuan peserta didik dan mendapatkan pengetahuan baru yang berasal dari proses menemukan. Dengan iklim pembelajaran seperti ini memudahkan peserta didik membangun kreativitas berpikir, melakukan identifikasi, serta memecahkan masalah secara nyata di lapangan. Selain itu, pembelajaran menggunakan model SBL memberikan kesempatan bagi peserta didik untuk belajar langsung dengan dunia nyata dan memberikan pegelaman unik yang tidak ditemukan di dalam kelas.

Pembelajaran menggunakan model SBL memberikan kesempatan bagi peserta didik untuk belajar langsung dengan dunia nyata dan memberikan pegelaman unik yang tidak ditemukan di dalam kelas. Pada proses pembalajaran peserta didik tidak hanya berperan sebagai penerima pasif, tetapi peserta didik berperan aktif untuk menemukan inti dari pembelajaran. Proses pembelajaran melalui model SBL sebagai salah satu upaya agar pembelajaran menjadi bermakna, efektif, dan menyenangkan. Selain itu, pembelajaran menggunakan model SBL menjadikan pembelajaran yang kontekstual karena tujuan dari model ini adalah membawa peserta didik mengamati, mengidentifikasi dan mempelajari permasalahan yang ada di lingkungan sekitar secara langsung. Model SBL dapat memberikan dampak positif dalam meningkatkan keterampilan sosial, kerjasama, dan komunikasi. Model pembelajaran SBL juga memberikan kesempatan bagi peserta didik untuk berkomunikasi dengan orang lain dan meningkatkan keaktifan dalam belajar.

\section{SIMPULAN}

Berdasarkan hasil uji hipotesis dan pembahasan, diambil kesimpulan bahwa model pembelajaran Spasial Based Learning berpengaruh signifikan terhadap kemampuan berpikir kritis siswa. Hal tersebut ditunjukkan dengan perolehan ratarata nilai gain score kemampuan berpikir kritis kelas eksperimen yang pada pembelajaran menggunakan model SBL lebih tinggi dibandingkan kelas kontrol yang pada pembelajaran menggunakan pembelajaran konvensional atau yang biasa digunakan. Rata-rata nilai gain score kemampuan berpikir kritis kelas eksperimen sebesar 25,53, sedangkan rata-rata nilai gain score kelas kontrol sebesar 13,23. Berdasarkan kesimpulan hasil penelitian ini, disarankan bahwa penerapan model pembelajaran SBL dapat menjadi alternatif pada pembelajaran geografi untuk meningkatkan kemampuan berpikir kritis peserta didik.

\section{DAFTAR RUJUKAN}

Arikunto, S. (2001). Dasar-Dasar Evaluasi Pendidikan. Jakarta: Bumi Aksara.

Bialik, M., \& Charles Fadel. (2017). Skills for the 21st Century: What Should Students Learn? (Center for Curriculumj Redesing). In 1 (Center for Curriculumj Redesing). Boston, Massachusetts: Montes Alti, Educational Fundation.

Boyles, N. (2014). Close Reading without Tears. Educational Leadership. Retrieved from http://www.researchgate.net/publication/amp.

BSNP. (2010). Paradigma Pendidikan Nasional Abad XXI. In 1.0. Jakarta.

Cromley, J. (2000). Learning to Think, Learning to Learn: What The Science of Thinking and Learning Has to Offer Adult Education. Washington, D. C. National Institute for Literacy 1775 I St., N. W., Suite 730.

Ennis, R. (1991). Critical Thinking: A Streamlined Conception. TeachingPhilosophy, University of Illinois, 1, 5-24. 
Ennis, R. H. (1985). Goals for Critical Thinking Curriculum in A. L. Costa, Developing Minds: A Resource Book for Teaching Thinking. Alexandria: Association for Supervisor and Curriculum Development (ASCD), 54-57.

Ennis, R. H. (1993). Critical Thinking Assessment. Theory into Practice, College of Education, The Ohio State University, 32, 179-186.

Gersmehl, P. (2008). Teaching Geography 2nd. In Royal Geographical Society: 42(3), 392-393. The Guilford Press.

Gul, R. B. (2014). Enhancing Educators' Skills for Promoting Critical Thinking in Their Classroom Discourses: A Randomized Control Trial. International Journal of Teaching and Learning in Higher Education, 26, 37-54.

Handoyo, B. (2017a). Kurikulum Transdisipliner dan Belajar Berbasis Kehidupan. Pembelajaran Berbasis Spasial dan Rancangan Implementasinya. In Kajian Inovasi Pembelajaran. Malang: Universitas Negeri Malang.

Handoyo, B. (2017b). Sustainable Spatial Skill (3S) sebagai Pengembangan Keterampilan Geografi. Journal Prosiding Seminar Nasional.

Mason, M. (2007). Critical Thinking and Learning. Blackwell Publishing, Journal Educational Philosophy and Theory, 10, 339-349. https://doi.org/10.1111/j.1469-5812.2007.00343.x

Mulyasa, E. (2013). Standar Kompetensi dan Sertifikasi Guru. Bandung: PT. Remaja Rosdakarya.

Saurino, D. R. (2008). Concept Journaling to Increase Critical Thinking Dispositions and Problem Solving Skills in Adult Education. The Journal of Human Resource and Adult Learning, 4, 170-178.

Sharma, M. B., \& Gary S. Elbow. (2000). Using Internet Primary Sources to Teach Critical Thinking Skills in Geography. In Greenwood Professional Guides in School Librarianship Harriet Selverstone, Series Adviser. London: Greenwood Press Publishing Group, Inc. Westport, Connecticut.

Slavin, R. E. (2008). Cooperative Learning: Teori, Riset dan Praktik. Bandung: Nusa Media.

Styron, R. A. (2014). Critical Thinking and Collaboration: A Strategy to Enhance Student Learning. Systemics, Cybernetics and Informatics, 12, 25-30.

Sugiyono. (2017). Metode Penelitian Kuantitatif, Kualitatif, dan $R$ \& D. Bandung: Alfabeta.

Sularmi., Utomo, D. H., \& Ruja, I. N. (2018). Pengaruh Project-Based Learning terhadap Kemampuan Berpikir Kritis. Jurnal Pendidikan: Teori, Penelitian, dan Pengembangan, 3(4), 475-479.

Syah, M. (2004). Psikologi Pendidikan dengan Pendekatan Baru. Bandung: PT Remaja Indonesia.

Trilling, B., \& Charles Fadel. (2009). 21st Century Skills, Learning for Life in Our Times (Jossey-Bass.). United States: Library of Congress Cataloging-in-Publication Data.

Utomo, D. H. (2016). Brain Based Learning: Effects Model A-Car in Critical Thinking Skills. Atlantis Press: Advances in Social Science, Education and Humanities Research, 79 (1st International Conference on Geography and Education), 339-343.

Wijayanti, A. P., Sumarmi., \& Amirudin, A. (2016). Perbandingan Model Group Investigation dengan Problem Based Learning Berbasis Multiple Intelligence terhadap Kemampuan Memecahkan Masalah Siswa SMA. Jurnal Pendidikan: Teori, Penelitian, dan Pengembangan, 1(5), 948-957.

Wolf, J. (2010). Critical Thinking in Physical Geography: Linking Concepts of Content and Applicability. Journal of Geography, 43-53. https://doi.org/10.1080/00221340903582289 